\title{
The Analysis of Student's difficulties Based on Skemp's Understanding Theorem at The Grade VII in Quadrilateral Topic
}

\author{
R H Kuncorowati ${ }^{1, a)}$, Mardiyana ${ }^{1, b)}$, D R S Saputro ${ }^{2, c)}$ \\ ${ }^{1}$ Department of Mathematics Education, Universitas Sebelas Maret, Jl. Ir. Sutami 36 A, \\ Kentingan, Surakarta 57126, Indonesia \\ ${ }^{2}$ Department of Mathematics Education, Universitas Sebelas Maret, Jl. Ir. Sutami 36 A, \\ Kentingan, Surakarta 57126, Indonesia \\ E-mail: ${ }^{\text {a) }}$ ririnherpina@gmail.com \\ b) mardiyana@staff.uns.ac.id \\ c) dewiretnoss@staff.uns.ac.id
}

\begin{abstract}
In learning process must be found the student's learning difficulties. The difficulties blocked students in learning process caused by several internal factors(talent, motive, intelligence, motivation) and external factors (family, teachers, peers). The student difficulty in learning general is caused by the lack of understanding of mathematical concepts. Skemp states that there are two types of mathematical concepts understanding, namely instrumental understanding and relational understanding. The purpose of research in this article is to describe the students' difficulties to solve the problem in a quadrilateral topic based on Skemp's Understanding theory. Skemp's Understanding theory indicators include : students ability to classify objects based on requirements that can build this concept, students ability to apply this concept with algorithm , students ability to giving examples of a concept, students ability to present the concept in mathematics representation, students ability to relating various mathematical concepts, and the ability to develop the necessary terms and conditions is quite a concept. This research was designed in qualitative research. The data was collected by test and interview. The results show that the most difficult is about the students ability to relating various mathematical concepts.
\end{abstract}

\section{INTRODUCTION}

Education is an effort to help students in developing themselves to be qualified person. The qualified student will be able to compete in science and technology development. In the teaching learning process, there are many obstacles found so that the students obtained un-optimal information. Many students have difficulty in using their cognitive ability to learn effectively. One of those problem is student learning difficulty. Those difficulties such as difficulty in making an accurate interpretation and perception, memorizing and finding facts, giving concentrations and using their logic thinking.

The students with high, average and low ability must be find learning difficulties in the different portion. The difficulties found by the student may happen when students doing the test. The mistakes made by the students in answering problem-based 
questions certain topic shows that the students have difficulty which is caused by the less of concept understanding about its topic. Richard Skemp referred to two types of understanding as relational understanding, "knowing what to do and why" and instrumental understanding, "rules without reason" [1]. Richard Skemp stated that the instrumental understanding basically not including understanding category, while relational understanding including understanding category. The statement insists that students have understood to the certain topic if they have reached a relational understanding.

In the instrumental understanding, the most finding problem is that in using that understanding type the student must be able to identify the type of the problem and associate a procedure to solve it. The problem is that too many types of problem-solving used to solve the certain mathematics problem. Many students memorize a procedure to solve the certin problem. The memorizing habit causes student is hard to solve mathematics problem with the suitable concept [10]. Students who attempt to understand relationally will try to correlate the new and old concepts then reflects the similarity and differences between the new concept and the previously learned concept.

The indicators of Skemp understanding were: 1) students ability in classifying objects based on the requirement which can form a concept. 2) students ability in applying the concept algorithmically. 3) students ability in giving examples of a concept, 4) the ability to repeat the learned concepts, 5) students ability to provide several mathematics concepts, 6) students ability to correlate several mathematics concepts, 7) the ability to develop necessary requirement and sufficient requirement of the certain concept.

A quadrilateral is one of topic that was taught at the seventh grade of Junior High School. This article is going to describe the students' difficulties in solving a quadrilateral problem based on Skemp understanding theory.

\section{METHODOLOGY}

This study used grounded theory, which is a suitable to analyze large quantities of unstructured or semi-structured data is qualitative [8]. The written test had been correlated with Skemp understanding indicator. The research used the structured interview in which the interviewer decide the problems and the questions that will be asked. The data result of the interview then used to clarify the data result of written test in where and what kind of difficulty experienced by the students. The subject of the research was the seventh-grade students of Kebakkramat 3 State Junior High School in which be taken with the high, average and low category of ability. The classification was based on the final test score of the first semester and teacher consultation. Based on the written test and interview, the researcher can conclude where is the students' difficulty with Skemp understanding category. 


\section{RESULT AND DISCUSSION}

The indicator of students' difficulty was correlated with the Skemp understanding indicator. The Skemp understanding theory stated that a child was called understand a topic if he or she was entering the relational understanding. [1]. The indicator of relational understanding was: 1) students ability in classifying objects based on the requirement which can form a concept. 2) students ability in applying the concept algorithmitically. 3) students ability in giving examples of a concept, 4) the ability to repeat the learned concepts, 5) studens ability to provide several mathematics concepts, 6) students ability to correlate several mathematics concepts, 7) the ability to develop neccesary requirement and sufficient requirement of certain concept. The students' difficulty based on their mistake in doing problem based question with rectangular topic and the interview result can be seen at this following table:

Table 1. Difficulties of High Ability Student

\begin{tabular}{|c|c|c|c|c|}
\hline No & Indicator & $\begin{array}{c}\text { Characteristic } \\
\text { Features }\end{array}$ & $\begin{array}{c}\text { Interview with } \\
\text { students }\end{array}$ & Possible Reasons \\
\hline 1 & $\begin{array}{l}\text { Students ability in } \\
\text { classifying } \\
\text { objects based on } \\
\text { the requirement } \\
\text { which can form a } \\
\text { concept }\end{array}$ & $\begin{array}{l}\text { a. In answering } \\
\text { problem-based } \\
\text { questions, } \\
\text { students do not } \\
\text { write down } \\
\text { what they know } \\
\text { in mathematics } \\
\text { symbols. } \\
\text { b. Students write } \\
\text { down the } \\
\text { formula to } \\
\text { answer the } \\
\text { problem. }\end{array}$ & $\begin{array}{l}\text { Students } \\
\text { understand the } \\
\text { aim of the } \\
\text { questions, but } \\
\text { they do not write } \\
\text { down what they } \\
\text { know and asked. } \\
\text { They count the } \\
\text { question directly }\end{array}$ & $\begin{array}{l}\text { Students are able } \\
\text { to classify objects } \\
\text { based on the } \\
\text { requirement } \\
\text { which can form a } \\
\text { concept }\end{array}$ \\
\hline 2 & $\begin{array}{l}\text { Students ability in } \\
\text { applying concept } \\
\text { algorithmatically }\end{array}$ & $\begin{array}{l}\text { Students can apply } \\
\text { the perimeter and } \\
\text { large of rectangular } \\
\text { concept of } \\
\text { rectangular to } \\
\text { answer the problem } \\
\text { based questions. }\end{array}$ & $\begin{array}{l}\text { Students } \\
\text { understand the } \\
\text { concept } \\
\text { perimeter and } \\
\text { large } \\
\text { rectangular so } \\
\text { they are able to } \\
\text { answer the } \\
\text { problem based } \\
\text { questions. }\end{array}$ & $\begin{array}{l}\text { Students are able } \\
\text { to apply concept } \\
\text { algorithmatically. }\end{array}$ \\
\hline 3 & $\begin{array}{l}\text { Students ability in } \\
\text { giving examples } \\
\text { of a concept }\end{array}$ & $\begin{array}{l}\text { Students can give } \\
\text { examples of } \\
\text { square, rectangle, } \\
\text { paralelogram, } \\
\text { diamond, rhombus }\end{array}$ & $\begin{array}{l}\text { Students are able } \\
\text { tomention the } \\
\text { features of these } \\
\text { rectangular } \\
\text { shapes. }\end{array}$ & $\begin{array}{l}\text { students are able } \\
\text { to giveexamples } \\
\text { of a concept }\end{array}$ \\
\hline
\end{tabular}




\begin{tabular}{|c|c|c|c|c|}
\hline & & d. & & \\
\hline 4 & $\begin{array}{l}\text { The ability to } \\
\text { repeat the learned } \\
\text { concepts }\end{array}$ & $\begin{array}{l}\text { Students can write } \\
\text { down the formula } \\
\text { of perimeter and } \\
\text { large of rectangular } \\
\text { shapes. }\end{array}$ & $\begin{array}{l}\text { Students are able } \\
\text { to mention the } \\
\text { formula of } \\
\text { perimeter and } \\
\text { large of } \\
\text { rectangular } \\
\text { shapes correctly. }\end{array}$ & $\begin{array}{l}\text { Students are able } \\
\text { to repeat the } \\
\text { learned concepts. }\end{array}$ \\
\hline 5 & $\begin{array}{l}\text { Studens ability to } \\
\text { provide several } \\
\text { representative } \\
\text { mathematics } \\
\text { concepts. }\end{array}$ & $\begin{array}{l}\text { Students can draw } \\
\text { the ilustrate of the } \\
\text { problem given and } \\
\text { the solution. }\end{array}$ & $\begin{array}{l}\text { Students can } \\
\text { draw the ilustrate } \\
\text { of the problem } \\
\text { given and the } \\
\text { solution. }\end{array}$ & $\begin{array}{l}\text { Students are able } \\
\text { to provide several } \\
\text { representative } \\
\text { mathematics } \\
\text { concepts. }\end{array}$ \\
\hline 6 & $\begin{array}{l}\text { Students ability to } \\
\text { correlate several } \\
\text { mathematics } \\
\text { concepts }\end{array}$ & $\begin{array}{l}\text { Students make } \\
\text { some mistakes in } \\
\text { counting by using } \\
\text { phytagoras } \\
\text { theorema. }\end{array}$ & $\begin{array}{l}\text { Students } \\
\text { understand the } \\
\text { formulas to } \\
\text { answer problem } \\
\text { based questions, } \\
\text { but they get } \\
\text { difficulty in } \\
\text { counting by using } \\
\text { phytagoras } \\
\text { theorema. }\end{array}$ & $\begin{array}{l}\text { Students are able } \\
\text { to correlate } \\
\text { several } \\
\text { mathematics } \\
\text { concepts }\end{array}$ \\
\hline 7 & $\begin{array}{l}\text { The ability to } \\
\text { develop neccesary } \\
\text { requirement and } \\
\text { sufficient } \\
\text { requirement of } \\
\text { certain concept }\end{array}$ & $\begin{array}{l}\text { Students can write } \\
\text { down the } \\
\text { requirements to } \\
\text { count and answer } \\
\text { the provided } \\
\text { questions. }\end{array}$ & $\begin{array}{l}\text { Students mention } \\
\text { the requirements } \\
\text { or steps that must } \\
\text { be done to } \\
\text { answer the } \\
\text { questons. }\end{array}$ & $\begin{array}{l}\text { Students are able } \\
\text { to develop } \\
\text { neccesary } \\
\text { requirement and } \\
\text { sufficient } \\
\text { requirement of } \\
\text { certain concept }\end{array}$ \\
\hline
\end{tabular}

From the discussion in Table 1, show that the difficulty in indicator number 6 . The result of the student's work showing the difficulty in this case be seen in Figure 1. 


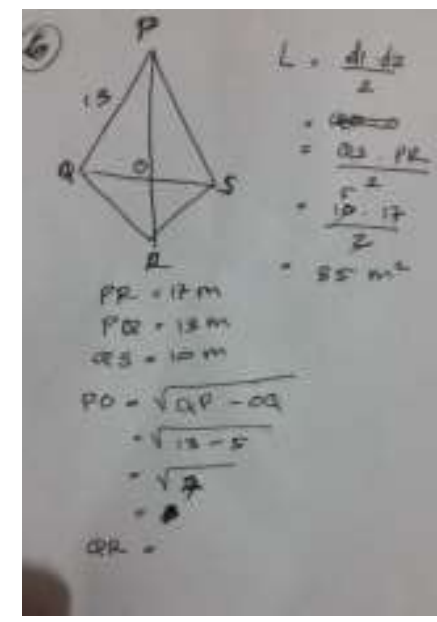

Figure 1

From the Figure 1, the student be correct in calculate the area of kite. But, to find length of OP students make a mistake in writing the formula of phytagoras theorem. In this case it means that students have difficulty in relating the previously accepted concept to the concept being studied.

Table 2. Difficulties of Average Ability Student

\begin{tabular}{|c|c|c|c|c|}
\hline No & Indikator & $\begin{array}{c}\text { Characteristic } \\
\text { Features }\end{array}$ & $\begin{array}{c}\text { Interview with } \\
\text { students }\end{array}$ & Possible Reasons \\
\hline 1 & $\begin{array}{l}\text { Students ability in } \\
\text { classifying } \\
\text { objects based on } \\
\text { the requirement } \\
\text { which can form a } \\
\text { concept }\end{array}$ & $\begin{array}{l}\text { a. In answering } \\
\text { problem based } \\
\text { questions, } \\
\text { students write } \\
\text { down what they } \\
\text { know into } \\
\text { mathematics } \\
\text { symbol. } \\
\text { b. The students } \\
\text { write down } \\
\text { formula to } \\
\text { answer problem } \\
\text { based questions. }\end{array}$ & $\begin{array}{l}\text { Students } \\
\text { understand the aim } \\
\text { of the questions } \\
\text { and able to explain } \\
\text { in mathematics } \\
\text { symbol. }\end{array}$ & $\begin{array}{l}\text { Students are able to } \\
\text { classify objects based } \\
\text { on the requirements } \\
\text { that can a concept. }\end{array}$ \\
\hline 2 & $\begin{array}{l}\text { Students ability in } \\
\text { applying concept } \\
\text { algorithmatically }\end{array}$ & $\begin{array}{l}\text { Students make } \\
\text { some mistakes in } \\
\text { counting the wide } \\
\text { of a rectangle } \\
\text { which had known } \\
\text { its perimeter, so } \\
\text { they have difficulty } \\
\text { in counting its } \\
\text { large. }\end{array}$ & $\begin{array}{l}\text { Students less } \\
\text { understand the } \\
\text { concept } \\
\text { rectangle perimeter } \\
\text { so they have } \\
\text { difficulty in } \\
\text { answering a } \\
\text { random questions. }\end{array}$ & $\begin{array}{l}\text { Students have } \\
\text { difficultyin applying } \\
\text { the concept } \\
\text { algorithmatically. }\end{array}$ \\
\hline 3 & $\begin{array}{l}\text { Students ability in } \\
\text { giving examples }\end{array}$ & $\begin{array}{lr}\text { Students can } & \text { give } \\
\text { examples } & \text { of }\end{array}$ & $\begin{array}{lr}\text { Students can } & \text { give } \\
\text { examples } & \text { of }\end{array}$ & $\begin{array}{lcr}\text { Students } & \text { can } & \text { give } \\
\text { examples } & \text { of } & \text { an }\end{array}$ \\
\hline
\end{tabular}




\begin{tabular}{|c|c|c|c|c|}
\hline & of an concept & $\begin{array}{lr}\text { square, rectangle, } \\
\text { diamond } & \text { and } \\
\text { rhombus, but } & \text { they } \\
\text { do not give } \\
\text { examples } \\
\text { parallelogram and } \\
\text { trapezoid. }\end{array}$ & $\begin{array}{l}\text { square, rectangle, } \\
\text { diamond and } \\
\text { rhombus because } \\
\text { they often see those } \\
\text { shapes in their } \\
\text { daily life, but they } \\
\text { seldom see the } \\
\text { objects which have } \\
\text { parallelogram and } \\
\text { trapezoid shapes. } \\
\text { However they are } \\
\text { able to describe the } \\
\text { features of each } \\
\text { shape. }\end{array}$ & concept \\
\hline 4 & $\begin{array}{l}\text { The ability to } \\
\text { repeat the learned } \\
\text { concepts }\end{array}$ & $\begin{array}{l}\text { Students can write } \\
\text { down the formula } \\
\text { of perimeter and } \\
\text { large of square and } \\
\text { rectangle but they } \\
\text { are not able to } \\
\text { write down the } \\
\text { formula of } \\
\text { perimeter and large } \\
\text { of parallelogram, } \\
\text { trapezoid and } \\
\text { rhombus. }\end{array}$ & $\begin{array}{l}\text { Students can } \\
\text { mention the } \\
\text { formula of } \\
\text { perimeter and large } \\
\text { of square and } \\
\text { rectangle, but they } \\
\text { are not able to } \\
\text { describe } \\
\text { features of each } \\
\text { shape. }\end{array}$ & $\begin{array}{l}\text { Students less in } \\
\text { repeating the learned } \\
\text { concept. }\end{array}$ \\
\hline 5 & $\begin{array}{l}\text { Students ability to } \\
\text { provide } \\
\text { theconcept into } \\
\text { mathematics } \\
\text { representation. }\end{array}$ & $\begin{array}{ll}\text { Students } & \\
\text { experience } & \text { of } \\
\text { errors when he } \\
\text { draw } \\
\text { ilustrations } \\
\text { problem. }\end{array}$ & $\begin{array}{l}\text { Students have } \\
\text { difficulty in draw } \\
\text { the illustrations of } \\
\text { problem. }\end{array}$ & $\begin{array}{l}\text { Students } \\
\text { difficulty in providing } \\
\text { concept } \\
\text { mathematics } \\
\text { representation. }\end{array}$ \\
\hline 6 & $\begin{array}{l}\text { Students ability to } \\
\text { correlate several } \\
\text { mathematics } \\
\text { concepts }\end{array}$ & $\begin{array}{l}\text { Students do some } \\
\text { mistakes in writing } \\
\text { phytagoras } \\
\text { theorema to count } \\
\text { the unknown side } \\
\text { of a triangle. }\end{array}$ & $\begin{array}{l}\text { Students have } \\
\text { difficulty in writing } \\
\text { phytagoras } \\
\text { theorema because } \\
\text { they do not } \\
\text { remember it well. }\end{array}$ & $\begin{array}{l}\text { Students have } \\
\text { difficulty in correlating } \\
\text { several mathematics } \\
\text { concepts. }\end{array}$ \\
\hline 7 & $\begin{array}{l}\text { The ability to } \\
\text { develop necessary } \\
\text { requirement and }\end{array}$ & $\begin{array}{l}\text { Students can write } \\
\text { down requirements } \\
\text { to solve the }\end{array}$ & $\begin{array}{l}\text { Students are able to } \\
\text { understand the } \\
\text { requirements and }\end{array}$ & $\begin{array}{l}\text { Students are able to } \\
\text { develop neccesary } \\
\text { requirement }\end{array}$ \\
\hline
\end{tabular}




\begin{tabular}{llll}
\hline $\begin{array}{l}\text { sufficient provided problem. } \\
\text { requirement of } \\
\text { certain concept }\end{array}$ & $\begin{array}{l}\text { steps in answering } \\
\text { the questions. }\end{array}$ & $\begin{array}{l}\text { sufficient requirement } \\
\text { of certain concept. }\end{array}$ \\
\hline
\end{tabular}

From the discussion in Table 2, it can be seen that there are student difficulties in indicator number 2. This can be seen in Figure 2.

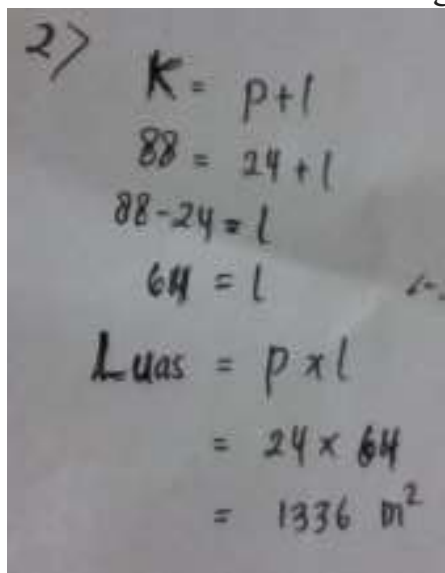

Figure 2

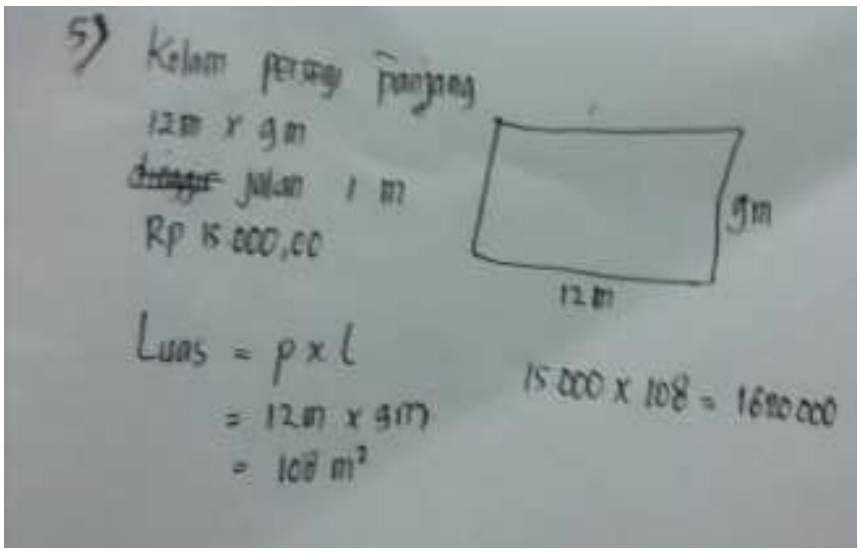

Figure 3

In Figure 2, the student is experienching an error in writing around of rectangle, So it can make an error in calculate the area of the rectangle. In Figure 3, show that the student have difficulty in indicator number 5. Students are seen not to write down what is known in the matter clearly and illustrated the picture is not appropriate.

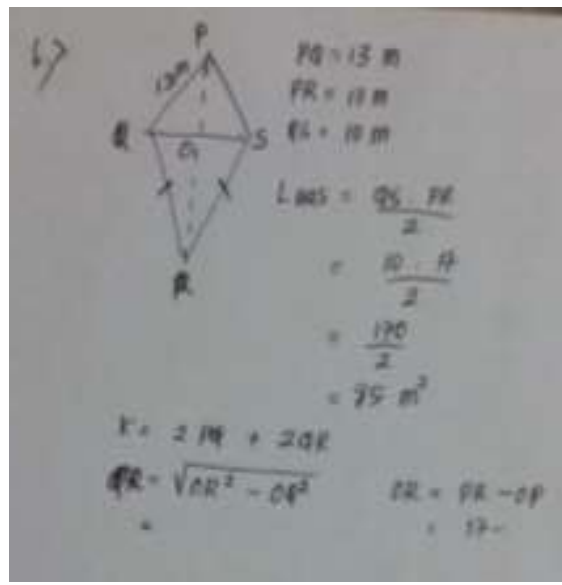

Figure 4

In Figure 4, the student experienced an error in writing the phytagoras theorem, so the student have difficulty in determining the length of the side.

Table 3. Difficulties of Low Ability Student

\begin{tabular}{|c|c|c|c|c|}
\hline No & Indikator & $\begin{array}{c}\text { Characteristic } \\
\text { Features }\end{array}$ & $\begin{array}{l}\text { Interview with } \\
\text { students }\end{array}$ & Possible Reasons \\
\hline 1 & Students ability in & answering & Students & Students \\
\hline
\end{tabular}




\begin{tabular}{|c|c|c|c|c|}
\hline & $\begin{array}{l}\text { classifying } \\
\text { objects based on } \\
\text { the requirement } \\
\text { which can form a } \\
\text { concept }\end{array}$ & $\begin{array}{l}\text { problem based } \\
\text { questions, } \\
\text { students do not } \\
\text { write down } \\
\text { what they know } \\
\text { into } \\
\text { mathematics } \\
\text { symbols. } \\
\text { b. Students make } \\
\text { some mistakes } \\
\text { in writing down } \\
\text { the formula to } \\
\text { answer problem } \\
\text { based questions. }\end{array}$ & $\begin{array}{l}\text { difficulty in } \\
\text { understanding the } \\
\text { aim of the } \\
\text { questions, so they } \\
\text { hard to write down } \\
\text { into mathematics } \\
\text { symbol }\end{array}$ & $\begin{array}{l}\text { difficulty in classifying } \\
\text { objects based on the } \\
\text { requirements which } \\
\text { can form a concept. }\end{array}$ \\
\hline 2 & $\begin{array}{l}\text { Students ability in } \\
\text { applying concept } \\
\text { algorithmatically }\end{array}$ & $\begin{array}{l}\text { Students make } \\
\text { some mistakes in } \\
\text { applying perimeter } \\
\text { and large of } \\
\text { rectangular shape } \\
\text { in answering } \\
\text { problem based } \\
\text { questions. }\end{array}$ & $\begin{array}{l}\text { Students are hard } \\
\text { to differentiate the } \\
\text { large formula of } \\
\text { several rectangular } \\
\text { shapes. }\end{array}$ & $\begin{array}{l}\text { Students are hard to } \\
\text { applying the concept } \\
\text { algorithmatically }\end{array}$ \\
\hline 3 & $\begin{array}{l}\text { students ability in } \\
\text { giving examples } \\
\text { of a concept }\end{array}$ & $\begin{array}{l}\text { Students can give } \\
\text { examples of } \\
\text { square, rectangle, } \\
\text { parallelogram, } \\
\text { diamond, rhombus } \\
\text { and trapezoid. }\end{array}$ & $\begin{array}{l}\text { Students can } \\
\text { mention the } \\
\text { features of each } \\
\text { rectangular shapes. }\end{array}$ & $\begin{array}{l}\text { Students can give } \\
\text { examples of a concept }\end{array}$ \\
\hline 4 & $\begin{array}{l}\text { The ability to } \\
\text { repeat the learned } \\
\text { concepts }\end{array}$ & $\begin{array}{l}\text { Students make } \\
\text { some mistakes in } \\
\text { writing down the } \\
\text { formula of } \\
\text { perimeter and large } \\
\text { of rectangular } \\
\text { shapes. }\end{array}$ & $\begin{array}{l}\text { Students have } \\
\text { difficulty in } \\
\text { differentiate the } \\
\text { formula } \\
\text { perimeter and large } \\
\text { of rhombus and } \\
\text { square. }\end{array}$ & $\begin{array}{l}\text { Students have } \\
\text { difficulty in repeating } \\
\text { the learned concepts. }\end{array}$ \\
\hline 5 & $\begin{array}{l}\text { Studens ability to } \\
\text { provide several } \\
\text { representative } \\
\text { mathematics } \\
\text { concepts. }\end{array}$ & $\begin{array}{ll}\text { Students } & \\
\text { experience } & \text { of } \\
\text { errors when he } \\
\text { draw } & \text { the } \\
\text { ilustrations } & \text { of } \\
\text { problem. } & \end{array}$ & $\begin{array}{l}\text { Students have } \\
\text { difficulty in draw } \\
\text { the illustrations of } \\
\text { problem. }\end{array}$ & $\begin{array}{l}\text { Students have } \\
\text { difficulty in providing } \\
\text { several representative } \\
\text { mathematics concepts }\end{array}$ \\
\hline 6 & $\begin{array}{l}\text { Students ability to } \\
\text { correlate several }\end{array}$ & $\begin{array}{l}\text { Students do some } \\
\text { mistakes in writing }\end{array}$ & $\begin{array}{l}\text { Students have } \\
\text { difficulty in writing }\end{array}$ & $\begin{array}{l}\text { Students have } \\
\text { difficulty in correlating }\end{array}$ \\
\hline
\end{tabular}




\begin{tabular}{|c|c|c|c|c|}
\hline & $\begin{array}{l}\text { mathematics } \\
\text { concepts }\end{array}$ & $\begin{array}{l}\text { phytagoras } \\
\text { theorema to count } \\
\text { the unknown side } \\
\text { of a triangle. }\end{array}$ & $\begin{array}{l}\text { phytagoras } \\
\text { theorema because } \\
\text { they do not } \\
\text { remember it well. }\end{array}$ & $\begin{array}{l}\text { several mathematics } \\
\text { concepts }\end{array}$ \\
\hline 7 & $\begin{array}{l}\text { The ability to } \\
\text { develop neccesary } \\
\text { requirement and } \\
\text { sufficient } \\
\text { requirement of } \\
\text { certain concept }\end{array}$ & $\begin{array}{l}\text { Students do not } \\
\text { write down the } \\
\text { requirements to } \\
\text { count and answer } \\
\text { the questions. }\end{array}$ & $\begin{array}{l}\text { Students are not } \\
\text { able to mention the } \\
\text { requirements and } \\
\text { steps to do in } \\
\text { answering that } \\
\text { problem based } \\
\text { questions. }\end{array}$ & $\begin{array}{lr}\text { Students } & \text { have } \\
\text { difficulty } & \text { in } \\
\text { developing } & \text { neccesary } \\
\text { requirement } & \text { and } \\
\text { sufficient requirement } \\
\text { of certain concept }\end{array}$ \\
\hline
\end{tabular}

From the discussion of Table 3, there are many difficulties experienced by low student's ability. The difficulties are found in indicators $1,2,4,5,6$, and 7 . The errors made on each of the indicators can be seen in Fig.

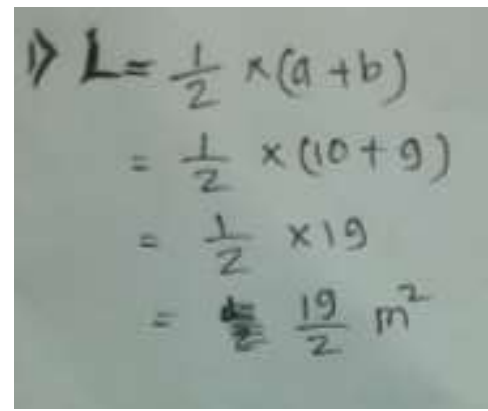

Figure 5

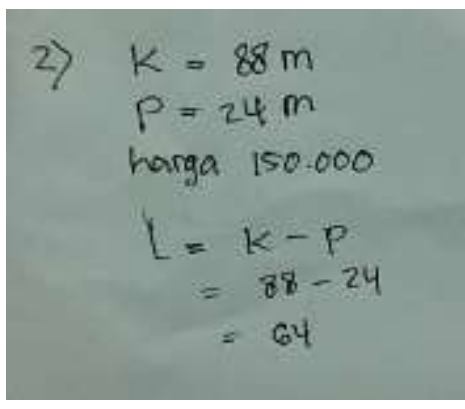

Figure 6

From Figure 5, show that the student's difficulty in indicator number 1. Tthe students did not write the known and asked questions and the students immediately answered by using the formula that he remembered. In the indicator number 1 is related to the trapezoid area. But students experience errors in writing the trapezoid formula. Figure 6 show that the student's difficulty in indicators number 2. Student error in finding the width of the rectangle and not finish it until it finds the area of the rectangle. Students also find it difficult to remember around the rectangle.

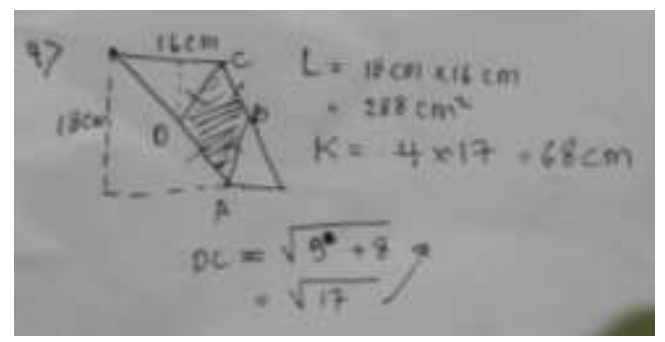

Figure 7 
In Figure 7, show that the student's difficulty in indicator number 4 and number 6 . The student's error in calculating the width of rhombus. Students also have difficulty in using the concept of phytagoras theorem.

Based on the explanation above, it can be known that the difficulty in answering rectangular shapes questions is also experienced by the average and high ability students. The same difficulty of them can be seen on the indicator of students' ability in correlating several mathematics concepts. Students have less skill in correlating the information they had learned to solve mathematics problem. In addition, students forget the concept that had been learned before. Based on the interview, students have difficulty in decide the steps to answer because they do not remember the any formula or concept that can be used to answer the questions given. The National Research Council (2001) points out the principles for helping students with learning difficulties: (1) Learning with understanding involves connecting and organizing knowledge; (2) Learning builds on what children already know; and (3) Formal school instruction should take advantage of children's informal everyday knowledge of mathematics [5].

In order to make the concepts received by the students long last, the learning model that can used by the teacher is discovery learning. According to Maarif, Discovery learning is learning by finding himself, investigating itself, the results obtained will be glued and durable in memory, not easily forgotten by the students [4].Balim said that:

"The discovery learning method necessitates the students' commenting on theconcepts, information, and Incidents by discussing and asking questions and reaching the information Themselves, in other words, discovering and finding the solution through practice. That is why the students should Participate in the class activities in groups and use the science labs more Actively. Using the discovery learning method, the which is one of the various teaching methods in the which the students are active and the teacher guides them, is Believed to increase of the students' success and inquiry learning skills more than traditional teaching methods do." [6]

By the right learning model, students will be able to receive the concept optimal and will minimize the learning difficulty. In addition to the learning model, motivation by the teacher to the students who make failure is also important. Slavin addresses four helpful general principles for supporting students with a tendency to accept failure: (1) Accentuate the positive. Understand the student's strengths and use these to develop their confidence; (2) Eliminate the negative. Deal with the student's weaknesses tactfully. Talk to the student and develop a plan to improve learning; (3) Go from the familiar to the new, using advanced organizers or guided discovery; and (4) Create challenges in which students actively create problems and solve them using their own knowledge and skills [7].

\section{CONCLUSION}

Learning difficulty experienced by students with high, average and low-ability. Low ability students have difficulties in some indicators of Skemp's Understanding Theorem. This should be noted by the teacher that the learning difficulties experienced 
by students is a problem that must be minimized. To minimize it, teacher should work to improve the learning process and provide motivation to students. Learning activities on quadrilateral topic should emphasize on discovery. Concepts that bulit by students can be durable. Learning model that can use is Discovery Learning.

\section{REFERENCES}

[1] Skemp, R. R. (1976). Relational Understanding and Instrumental Understanding. Mathematics Teaching, 77, 20-26.

[2] For a fuller discussion see R. R. Skemp: The Psychology of Learning Mathematics (Penguin 1972) pp. 43-46.

[3] Tarzimah T, Thamby S. Students' Difficulties in Mathematics Problem-Solving: What do they Say?.Procedia Social and Behavioral Sciences 8 (2010) 142-151.

[4] Maarif, S. Improving junior high school students' mathematical analogical ability using discovery learning method. International Journal of Research in Education and Science (IJRES), 2(1), 114- 124, (2016).

[5] National Research Council. (2001). Adding it up: Helping children learn mathematics. In J. Kilpatrick, J. Swafford, \& B. Findell (Eds.). Mathematics learning study committee, center for education, Washington, DC: National Academy Press.

[6] Balım, A. G. The Effects of Discovery Learning on Students' Success and Inquiry Learning Skills. Eurasian Journal of Educational Research35, 1-20 (2009).

[7] Slavin, R. (2003). Educational psychology: Theory and practice (7th ed). Boston, MA: Allyn and Bacon

[8] Lawrence, J, Tar, U. (2014). The use of grounded theory technique as a practical tool for qualitative data collection and analysis. Journal of Travel \& Tourism Marketing, 31(3), 417-442.

[9] Jiban, C. L., \&Deno, S. L. (2007). Using math and reading curriculum-based measurements to predicts state mathematics test performance: Are simple oneminute measures technically adequate?. Assessment of Effective Intervention, 32(2), 78-89.

[10] Goldin, G. A. (1998). Representational System Learning and Problem Solving in Mathematics. Journal of Mathematical Behaviour 17(2):137- 165 